\title{
PERANCANGAN MEDIA VISUAL INTERACTIVE MAPS SEBAGAI MEDIA PEMBELAJARAN BAHASA INGGRIS
}

\author{
Edo Galasro Limbong ${ }^{1}$; Riana Hoseani ${ }^{2}$ \\ Dosen Desain Komunikasi Visual ${ }^{1,2}$ \\ Universitas Indraprasta PGRI Jakarta \\ Email: edogalasro_limbong@yahoo.com ${ }^{1}$
}

\begin{abstract}
Abstrak
Sebagian orang berpendapat bahasa Inggris dianggap sesuatu yang menakutkan. Akan tetapi, saat ini bahasa Inggris sangat dibutuhkan baik secara aktif dan pasif. Sehingga pembelajaran bahasa Inggris memiliki suatu kurikulum dalam dunia pendidikan di Indonesia. Bahkan setiap individu harus berbicara dalam bahasa Inggris dalam setiap kesempatan. Dalam meningkatkan kemampuan bahasa Inggris tersebut dapat dilakukan dengan berlatih secara berulang. Dan untuk hasil yang lebih maksimal dibutuhkan media pembelajaran bahasa Inggris yang sifatnya interaktif. Hal ini yang diperlukan oleh anak-anak usia sekolah menengah pertama di panti asuhan Abigail. Dengan demikian tujuan dalam penulisan ini adalah untuk merancang media visual interactive maps sebagai media pembelajaran bahasa Inggris. Dalam penulisan ini menggunakan metode penelitian dan pengembangan dengan teknik pengumpulan data studi pustaka, observasi, dan wawancara. Adapun hasil yang diperoleh adalah media interactive maps dibuat dengan gambar dan bentuk yang menarik bisa digunakan sebagai media edukasi bagi usia sekolah menengah pertama. Selain itu, media tersebut dapat dipegang langsung saat kegiatan belajar.
\end{abstract}

Kata Kunci: Interactive Maps, Media Pembelajaran, Speaking, Bahasa Inggris

\begin{abstract}
Some people consider English as something scary. However, English is currently much needed both actively and passively. Therefore, learning English has a curriculum in the world of education in Indonesia. Even every individual must speak in English at every opportunity. In improving English language skills, it can be done by practicing repeatedly. And for maximum results, an interactive learning media for English is needed. This is what is needed by junior high school-aged children at the Abigail orphanage. Thus the purpose of this paper is to design visual interactive maps media as a medium for learning English.Tthis paper used research and development methods with data collection techniques were study literature, observation, and interviews. The result obtained was interactive maps media created with attractive images and shapes that can be used as educational media for junior high school age. In addition, the media can be held directly during learning activities.
\end{abstract}

Key Words: Interactive Maps, Learning Media, Speaking, English

\section{PENDAHULUAN}

Masyarakat Indonesia pada era globalisasi saat ini telah menjadi bagian dari masyarakat dunia yang menuntut setiap orang untuk dapat berinteraksi dan berkomunikasi antarnegara. Bahasa merupakan alat komunikasi yang dibutuhkan dalam penyampaian pesan kepada orang lain. Dalam kaitan dengan kebutuhan globalisasi, menempatkan bahasa Inggris sebagai bahasa Internasional. Bahasa Inggris juga berfungsi sebagai jembatan ilmu pengetahuan dalam pengembangan IPTEK, mengingat banyaknya literatur dalam bahasa Inggris. Dunia pendidikan tingkat lanjut dan dunia kerja juga menuntut setiap individu untuk memiliki kemampuan berbahasa Inggris secara aktif ataupun pasif, terlebih dalam hal berbicara dalam Bahasa Inggris. Oleh sebab itu, dapat dilihat bahwa bahasa Inggris telah menjadi kebutuhan semua kalangan masyarakat, sehingga pendidikan bahasa Inggris menjadi suatu hal yang penting. 
Pentingnya memahami bahasa Inggris menjadikan bahasa Inggris masuk ke dalam kurikulum pendidikan di Indonesia. Pengajaran bahasa Inggris di Indonesia diberikan pada usia dini dan termasuk dalam salah satu mata pelajaran di sekolah SD, SMP dan SMA. Menurut Matlin [1] anak yang menguasai dua bahasa cenderung fleksibel dan kreatif serta menunjukan kelebihan pada tes kecerdasan nonverbal yang membutuhkan pengaturan ulang dari petunjuk yang dapat dilihat dan pada tugas dalam konsep yang membutuhkan fleksibilitas mental. Ditambah menurut Cummins (1987) dan Zeev (1977) dalam Ninawati [1], anak yang menguasai dua bahasa juga memperlihatkan orientasi analisis yang lebih baik.

Pada prosesnya belajar bahasa Inggris bisa menyenangkan, akan tetapi juga bisa membosankan atau menyulitkan. Perasaan sulit atau bosan menuntut para pengajar atau guru untuk kreatif dalam kegiatan belajar dan mengajar. Permasalahan tersebut terjadi diantara siswa sekolah kebanyakan dan khususnya pada penelitian ini ditemukan juga pada anak-anak di Panti Asuhan Abigail, secara khusus bagi anak-anak usia sekolah menengah pertama (SMP). Anak-anak usia SMP di Panti Asuhan Abigail hanya memiliki buku pelajaran bahasa Inggris sebagai media belajar. Ditambah lagi kakak pembimbing mereka di panti asuhan memiliki keterbatasan dalam penguasaan bahasa Inggris, sehingga menimbulkan rasa enggan dan jenuh dalam melatih kemampuan bahasa Inggris. Mengatasai permasalahan tersebut dapat dilakukan sebuh metode belajar melalui permainan. Siswa akan cenderung lebih giat belajar ketika merasa memiliki kemajuan dalam belajar, dan permainan menyediakan kesempatan bagi siswa untuk berlatih dan menghilangkan kejenuhan, ketakutan dan rasa malas. Oleh sebab itu, untuk mendukung hal tersebut dibutuhkan sebuah media pembelajaran.

Media pembelajaran pada saat ini sudah sangat beragam. Kemajuan teknologi membuat telepon genggam dan laptop dapat difungsikan sebagai media pembelajaran. Akan tetapi, media tersebut masih tergolong mahal atau belum terjangkau bagi sebagian masyarakat. Selain itu juga media tersebut memiliki efek samping terhadap kesehatan bila digunakan secara tidak bijak. Ketergantungan telepon genggam dapat mempengaruhi perubahan mental dan interaksi sosial dengan lingkungan sekitar.

Berdasarkan pemaparan tentang pentingnya kemampuan berbahasa Inggris pada masa kini, dan perlunya pemenuhan kebutuhan akan media pembelajaran yang tepat, maka pada tulisan ini akan dipaparkan mengenai perancangan media pembelajaran bahasa Inggris yang mampu memotivasi dan memudahkan anak usia sekolah, khususnya siswa sekolah menengah pertama.

\section{METODE PENELITIAN}

Metode yang digunakan yaitu metode penelitian dan pengembangan atau yang dikenal dengan research and development. Menurut Sugiyono[2] metode penelitian dan pengembangan adalah metode penelitian yang digunakan untuk menghasilkan produk tertentu, dan menguji keefektifan produk tersebut.

Pada penelitian ini teknik pengumpulan data yang dilakukan adalah observasi, wawancara, dan literatur. Data yang didapatkan atau dikumpulkan berasal dari hasil mengamati kegiatan belajar anak-anak di panti asuhan Abigail dan data literatur berupa buku dan jurnal yang berkaitan dengan metode belajar, media pembelajaran dan yang berkaitan dengan kebutuhan perancangan interactive maps. 
Berdasarkan observasi yang dilakukan terhadap ketersediaan media pembelajaran bahasa inggris, ditemukan bahwa anak-anak usia sekolah menengah pertama hanya memiliki media pembelajaran dalam bentuk buku dan mereka merasa enggan untuk melatih kemampuan bahasa Inggrisnya di luar sekolah. Hal ini berdasarkan pada faktor biaya yang terbatas, dan kesiapan pendamping dalam membuat media pembelajaran.

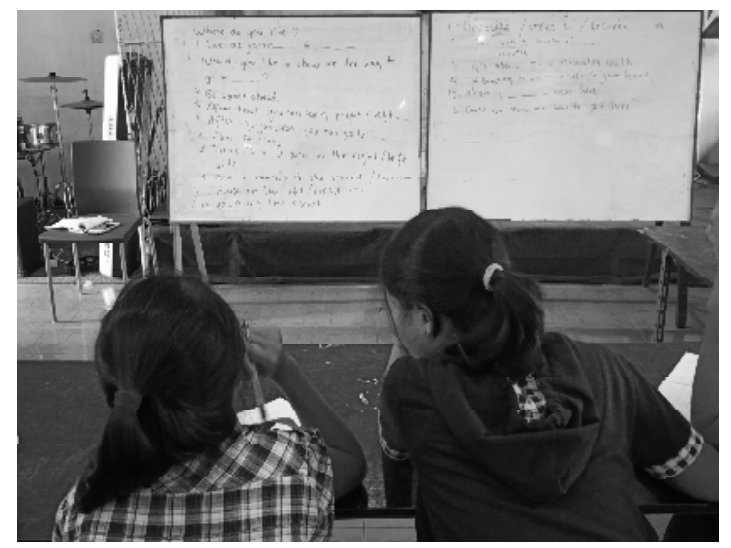

Gambar 1. Situasi belajar di dalam ruangan

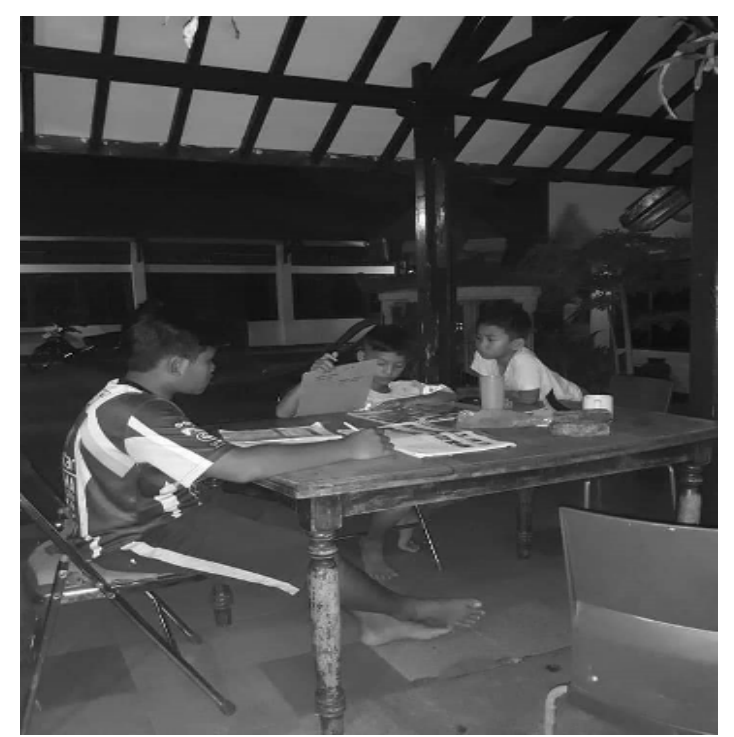

Gambar 2. Situasi belajar di luar ruangan

HASIL DAN PEMBAHASAN
Belajar sebagai proses perubahan perilaku sebagai hasil interaksi individu dengan lingkungannya, di mana perubahan perilaku dari hasil belajar sifatnya berkelanjutan, fungsional, aktif, dan terarah [3]. Melalui belajar setiap individu menunjukkan perubahan yang diperlihatkan dalam perubahan tingkah laku yang berbeda dari keadaan sebelum individu tersebut belajar. Berbeda dengan perubahan serta merta akibat refleks atau perilaku yang bersifat naluriah, perubahan perilaku ketika individu belajar terjadi akibat adanya suatu pengalaman atau latihan.

Belajar dilakukan oleh manusia mulai dari usia anak-anak hingga dewasa. Setiap individu melakukan berbagai cara dan menggunakan berbagai media untuk memperoleh ilmu. Media yang digunakan dalam mencari ilmu tersebut dapat dikatakan sebagai media pembelajaran. Bovee dalam Supriatna[4], mengungkapkan bahwa media adalah sebuah alat yang mempunyai fungsi menyampaikan pesan. Kemudian menurut Oemar Malik [5] pembelajaran merupakan kombinasi terorganisir meliputi unsur-unsur manusiawi, material, perlengkapan dan prosedural yang saling berinteraksi untuk mencapai tujuan tertentu. Dengan demikian, media pembelajaran merupakan sebuah alat yang dibuat secara terorganisir yang memiliki fungsi dalam menyampaikan pesan untuk mencapai tujuan tertentu[5].

Bagi anak-anak usia sekolah, media pembelajaran dapat menambah pengalaman karena mereka mencoba memahami sebuah materi pembelajaran dengan media tersebut. Media pembelajaran tersebut diharapkan sifatnya yang interaktif. Apabila media pembelajaran tersebut sifatnya interaktif, maka dapat mengurangi rasa suntuk seseorang pada saat lelah membaca buku. Pada sisi lain, adanya suatu media pembelajaran dapat 
menjadi penghubung bagi pengajar dalam menjelaskan materi kepada siswanya. Sehingga, para pengajar tidak akan merasa kesusahan dalam memberi penjelasan, serta siswapun lebih mudah untuk memahami materi yang sedang dipelajari. Begitu pula bagi para orang tua, media pembelajaran dapat dijadikan sebagai pendukung dalam memberikan contoh kepada anaknya disaat mendampingi belajar di rumah.

Heinich dan Molenda [4], mengatakan bahwa terdapat enam jenis dasar dari media pembelajaran, yaitu: (1) Teks; (2) Media Audio; (3) Media Visual; (4) Media Proyeksi Gerak; (5) Benda-benda Tiruan/Miniatur; dan (6) Manusia. Dari enam media diatas, yang mayoritas digunakan salah satunya adalah media visual. Dalam media visual, pesan yang akan disampaikan dituangkan ke dalam simbol-simbol visual, seperti gambar atau foto, sketsa, diagram, bagan, grafik, kartun, poster, peta, papan planel serta papan bulletin.

Media pembelajaran dalam bentuk visual akan membuat komunikasi yang efektif dalam pemahaman materi di dalam kelas. Pada Lankow, dkk. [6] media visual dapat menimbulkan suatu daya pikat atau menarik perhatian serta menyenangkan sehingga perhatian terfokus dan mudah mengangkap pada pesan yang ingin disampaikan. Lalu, dengan menggunakan media visual dapat memperoleh informasi lebih banyak melalui sistem visual daripada yang bisa didapatkan melalui gabungan semua indera. Serta bila menggunakan media visual, maka tidak mudah untuk dilupakan oleh seseorang karena adanya memori jangka panjang pada otak manusia.

\section{Permasalahan}

Berdasarkan hasil pengamatan situasi yang dilakukan ke panti asuhan Abigail, pada panti asuhan ini media pembelajaran yang khusus

untuk usia Sekolah Menengah Pertama (SMP) masih sangat minim. Mayoritas yang ada adalah media yang dapat digunakan mulai dari usia bayi hingga Sekolah Dasar (SD). Sehingga anak-anak yang usia SMP tersebut hanya menggunakan berbagai buku bacaan saja sebagai media pembelajarannya seharihari. Sehingga anak-anak tersebut semakin kesulitan bila harus melakukan praktek apabila mereka memliki tugas praktek. Ditambah lagi, semua anak usia SMP tersebut tidak memiliki gadget pribadi. Selain itu, panti pun hanya memiliki satu unit komputer serta tidak memiliki akses internet.

Tidak hanya itu saja, permasalahan lainnya yang dihadapi oleh mereka adalah masih kurangnya anak-anak usia SMP untuk berlatih berbicara dalam bahasa Inggris. Berdasarkan hasil penuturan oleh seorang pelaksana harian panti, ibu Mini, anak-anak usia SMP tersebut mencoba berbicara bahasa Inggris hanya disekolahnya saja, sedangkan pada saat pulang ke panti mereka malas untuk mempraktikkannya. Selain itu, memang diakui oleh ibu Mini, beliau dan para kakak pendamping masih terbatas dalam bahasa Inggris. Sehingga, hal tersebut menjadi alasan untuk anak-anak panti tidak mau mencoba praktik berbicara dalam bahasa Inggris.

Kurangnya alternatif media pembelajaran yang interaktif dalam proses belajar mengajar terutama bagi anak-anak usia Sekolah Menengah Pertama, diperlukan pengembangan media pembelajaran yang interaktif untuk dapat digunakan di dalam kelas. Media pembelajaran yang dibuat berupa Interactive Maps. Media pembelajaran ini dapat digunakan sambil bermain untuk lebih berani dan aktif berbicara dalam bahasa Inggris.

\section{Perancangan}


Media pembelajaran bahasa Inggris yang dirancang adalah dalam bentuk Interactive maps. Interactive Maps tersebut berfungsi sebagai sebuah permainan menunjukan suatu lokasi. Melalui permainan ini para peserta akan berlatih untuk berbicara dalam bahasa inggris. Kelebihan belajar dengan media ini adalah peserta akan dengan mudah memvisualisasikan arah atau direction seperti menunjukan suatu lokasi menggunakan sebuah peta. Akan berbeda halnya apabila tanpa alat bantu maka peserta hanya dapat berbicara sambil berimajinasi saja.

Terdapat enam prinsip motivasi menurut Flemming dan Levie[7] yang menjadi acuan ketika mendesain teks dan gambar yang digunakan dalam menyajikan pesan pembelajaran yaitu (1) menciptakan kesan positif, yaitu bahwa berlatih berbicara bahasa Inggris tidak sulit dan dapat dilakukan dengan cara bermain; (2) keterbacaan teks, tipografi yang digunakan dalam perancangan adalah jenis huruf sans serif "Tahoma" karena dinilai memiliki tingkat keterbacaan yang tinggi. Teks dalam peta sebagai keterangan gambar yang menunjukan nama bangunan;(3) kejelasan gambar, gambar merupakan representasi konkret dari pesan yang disajikan. Gambar ilustrasi pada peta dibuat sederhana dan menggunakan label (nama gambar) agar tidak terjadi kesalahan persepsi; (4) kemudahan tata letak; (5) kemenarikan gambar, peta dibuat dengan menggunakan gambar perspektif, menggunakan bentuk mobil sebagai avatar pemain, dan dibuat berwarna agar lebih menarik; (6) bangkitkan minat.

Media pembelajaran dibuat dalam bentuk peta dengan alasan berlatih menunjukan arah merupakan latihan sederhana yang bisa diaplikasikan dalam kehidupan sehari-hari ketika mereka berjalan dari satu lokasi ke lokasi lainnya, misal ketika mereka berangkat dari panti asuhan menuju ke sekolah masingmasing. Oleh sebab itulah maka peta kota yang dipilih dalam perancangan interactive maps ini.

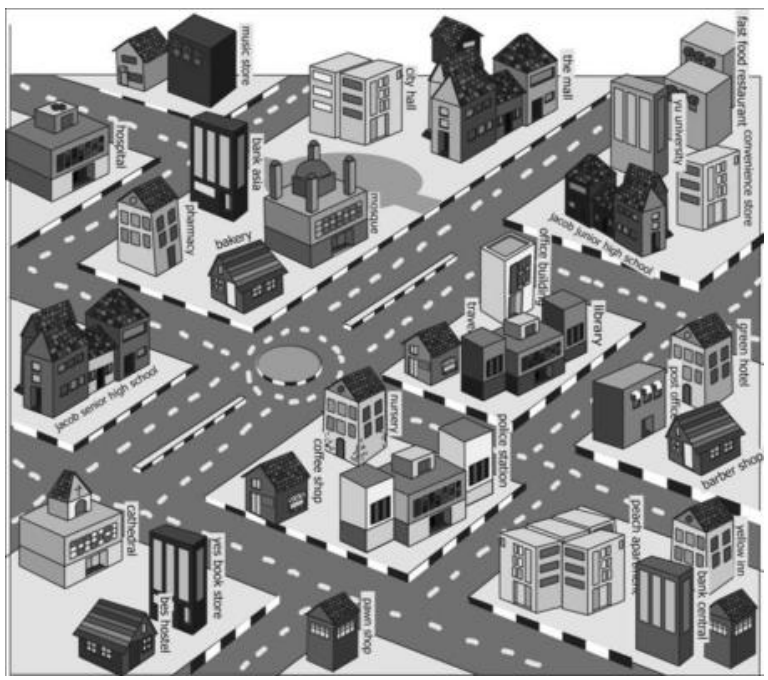

Gambar 3. Interactive Maps

Interactive Maps yang dibuat berbentuk sebuah peta menggunakan ilustrasi semi realis dengan pilihan warna yang relatif cerah. Peta dibuat terdiri atas tiga bagian. Pertama adalah peta yang memuat gambar denah jalan saja, pada peta tersebutlah nantinya bangunanbangunan di tata sedemikian rupa sehingga seperti sebuah denah $\mathrm{k}$ ota. Bagian ini dibuat dengan ukuran $60 \times 80 \mathrm{~cm}$, dibuat besar agar ketika dimainkan di depan kelas dapat terliht dengan jelas oleh seluruh peserta atau siswa.

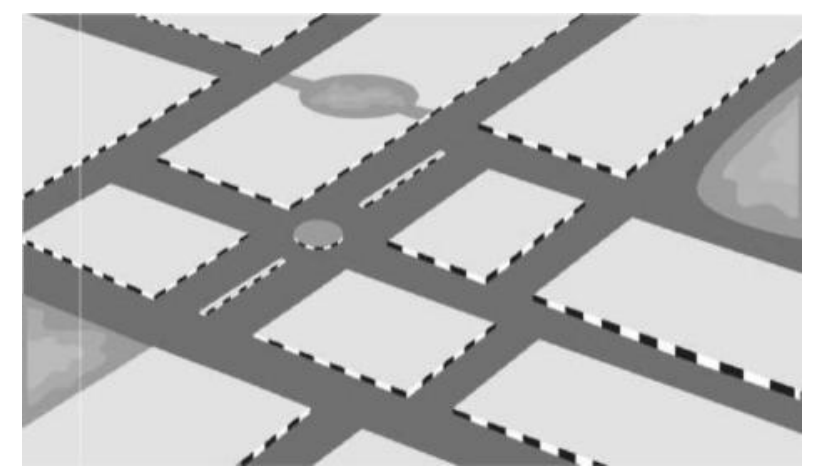

Gambar 4. Denah Jalan Pada Interactive Maps 
Kemudian bagian kedua adalah bangunan seperti rumah, restoran, rumah sakit, perpustakaan, tempat ibadah, dan lain-lain. Bangunan-bangunan ini dipilih menyesuaikan dengan keadaan sebenarnya yang berada di jalanan bahwa bangunan-bangunan tersebut umum untuk didatangi oleh orang banyak. Selain itu, bangunan-bangunan tersebut lazim tersedia pada negara-negara di luar Indonesia. Bangunan tersebut tidak dibuat menyatu dengan denah jalan agar dapat di bongkarpasang, sehingga denah kota akan dapat berubah sesuai dengan imajinasi yang memainkan, sehingga tidak akan jenuh memainkannya berulang kali.

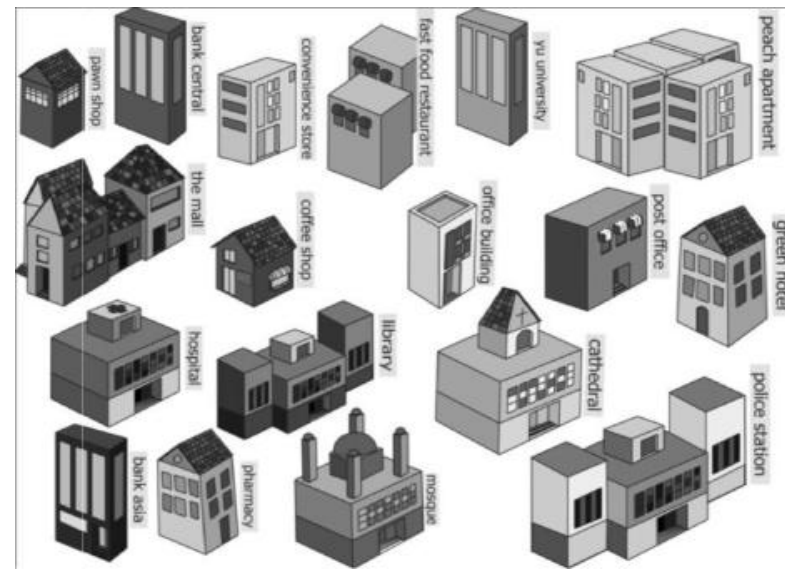

Gambar 5. Beberapa Gambar Bangunan Pada Interactive Maps

Bagian ketiga adalah bentuk kendaraan berupa mobil yang berfungsi sebagai avatar bagi para peserta didik, menyesuaikan dengan bentuk denah yang merupakan sebuah kota maka untuk avatar dipilih bentuk mobil. Dengan juga mempertimbangkan bahwa mobil bisa merepresentasikan pemain atau peserta tanpa mempedulikan gender. Warna mobil juga dibuat beragam sehingga lebih netral dan dapat dipilih oleh anak laki-laki ataupun perempuan sebagai avatar mereka.

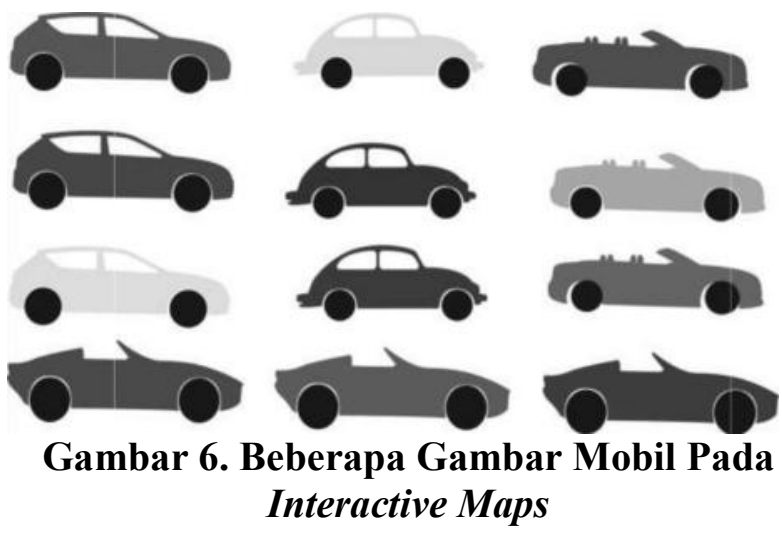

Cara memainkannya adalah setiap anak dapat memberikan pertanyaan kepada temannya tentang bagaimana cara menuju ke suatu tempat dari titik awal yang pilih secara bergantian atau pun dilakukan oleh pengajar yang dapat meminta anak-anak untuk menunjukan arah dari satu titik ke titik lain dan seterusnya. Fokus utamanya adalah anak berani untuk meningkatkan kemampuan bahasa Inggris melalui praktek berbicara dalam bahasa Inggris dengan menunjukan arah yang dituju menggunakan peta sambil menggerakkan avatar.

\section{SIMPULAN}

Melalui Interactive Maps, diharapkan akan menambah motivasi dan semangat belajar, menambah pengetahuan, serta mengasah kemampuan bahasa Inggris anak-anak panti asuhan yang usia SMP dalam hal speaking (berbicara) dalam bahasa Inggris. Media pembelajaran Interactive Maps didesain dalam ukuran yang besar supaya dalam dilihat secara jelas. Selain itu, media tersebut merupakan media visual yang akan menggunakan tambahan gambar-gambar yang menarik dan berwarna untuk dapat menarik perhatian. dapat memberikan solusi dan membantu memberikan suasana baru dalam mengaplikasikan pelajaran Bahasa Inggris. Dengan demikian belajar bahasa Inggris bukan lagi menjadi hal yang sulit, akan tetapi menyenangkan. 


\section{DAFTAR PUSTAKA}

[1] M. Ninawati, "Kajian Dampak Bilingual Terhadap Perkembangan Kognitif Anak Sekolah Dasar," J. Ilm. Widya, 2012.

[2] Sugiyono, METODE PENELITIAN Kuantitatif, Kualitatif, dan $R \& D$. Bandung: ALFABETA, 2018.

[3] A. Pane, "BELAJAR DAN PEMBELAJARAN," FITRAH, vol. 03, pp. 333-352, 2017.

[4] D. Supriatna, "Model dan Metode Pembelajaran Di Sekolah," 2009.

[5] Syifa S. Mukrimaa, 53 Metode Belajar dan Pembelajaran Plus Aplikasinya. Bandung: Universitas Pendidikan Indonesia, 2014.

[6] J. Lankow, J. Ritchie, and R. Crooks, INFOGRAFIS Kedasyatan Cara Bercerita Visual. Jakarta: PT Gramedia Pustaka Utama, 2014.

[7] I Komang Sudarma; I Made Teguh; Dewa Gede Agus Putra Prabawa, DESAIN PESAN KAJIAN ANALITIS DESAIN VISUAL Teks dan Image. Yogyakarta: Graha Ilmu, 2015. 